\title{
20. DISTRIBUTION OF HOLOCENE BENTHIC FORAMINIFERS IN THE IZU-BONIN ARC ${ }^{1}$
}

\author{
Kunio Kaiho ${ }^{2}$ and Akira Nishimura ${ }^{3}$
}

\begin{abstract}
The distribution of Holocene benthic foraminifer species in bottom sediments in the Izu-Bonin Arc region of the northwestern Pacific Ocean has been investigated on the basis of 23 samples recovered from depths between 1100 and $4100 \mathrm{~m}$. The benthic foraminifer faunas identified can be grouped into four species assemblages corresponding to four bathymetric zones: the abyssal zone (below $3700 \mathrm{~m}$ water depth), lower bathyal zone $(2600-3600 \mathrm{~m})$, lower middle bathyal zone (1600-2300 m), and upper middle bathyal zone (above $1300 \mathrm{~m}$ ). The dominance of such an agglutinated foraminifer as Rhabdamminella sp. characterizes the abyssal zone, whereas assemblages devoid of calcareous foraminifers distinguish the zone deeper than the carbonate compensation depth (CCD). The occurrence of Bulimina aculeata d'Orbigny enables the recognition of the following three bathymetric zones: the lower bathyal zone characterized by such deep-sea species as Oculosiphon sp., Saccorhiza ramosa (Brady), Alabamina sp., and Pullenia bulloides (d'Orbigny); the lower middle bathyal zone defined by the occurrence of $B$. aculeata; and the upper middle bathyal zone characterized by the lack of $B$. aculeata as well as the dominance of such species as Uvigerina proboscidea Schwager and Sphaeroidina bulloides d'Orbigny.

To estimate Quaternary and Pliocene paleobathymetry in the Izu-Bonin region, three water-depth indexes will work well: $3700 \mathrm{~m}$ for the CCD, $2300 \mathrm{~m}$ for the deepest habitat of B. aculeata, and $1600 \mathrm{~m}$ for the shallowest habitat of $B$. aculeata.
\end{abstract}

\section{INTRODUCTION}

The first record of Holocene smaller benthic foraminifers from the Izu-Bonin region is contained in this report. The purpose of this study is to clarify the distribution of Holocene calcareous benthic foraminifers in the middle bathyal to abyssal depths. Kaiho used the results to estimate paleowater depths of this region in this volume (Kaiho, this volume).

Figure 1 and Table 1 show sampling localities and water depths. Table 2 presents the distribution of benthic foraminifers and their abundances as well as planktonic foraminifer abundance and preservation. Plates 1 through 5 cover most of the species found in the present study.

\section{MATERIALS AND METHODS}

We investigated the distribution of Holocene benthic foraminifer species in bottom sediments in the Izu-Bonin Arc region of the northwestern Pacific Ocean between latitudes of $27^{\circ} 30^{\prime} \mathrm{N}$ and $33^{\circ} 32^{\prime} \mathrm{N}$ on the basis of 23 samples recovered from depths between 1100 and $4100 \mathrm{~m}$. Of these, 21 samples consist of mud recovered from a 4- to 5-cm depth below seafloor that were collected by a pilot corer of Hakurei-maru of Geological Survey of Japan and 2 samples are mud taken from 2- to 4-cm depths below seafloor during Ocean Drilling Program (ODP) Leg 126 drilling at Sites 790 and 792.

In the top $1 \mathrm{~cm}$ of samples from the same sites, agglutinated foraminifers are very abundant, but calcareous benthic foraminifers are rare. Because samples from a 4- to $5-\mathrm{cm}$ depth below seafloor contain more calcareous benthic foraminifers, we used them to analyze the distribution of Holocene benthic foraminifer species. This selection of deeper level samples was made because calcareous foraminifers occupy most of the fossil assemblages occurring in bathyal depths of the Izu-Bonin region (Kaiho, this volume).

Samples were washed through a 250 -mesh screen $(63-\mu \mathrm{m}$ opening) and dried.

${ }^{1}$ Taylor, B., Fujioka, K., et al., 1992. Proc. ODP, Sci. Results, 126: College Station, TX (Ocean Drilling Program).

${ }^{2}$ Institute of Geology and Paleontology, Tohoku University, Sendai 980, Japan.

${ }^{3}$ Geological Survey of Japan, 1-1-3 Higashi, Tsukuba 305, Japan.

\section{RESULTS}

We differentiated four species assemblages: Assemblage A, B, C, and $\mathrm{D}$. These assemblages correspond to the following four bathymetric zones (Fig. 2): the abyssal zone ( $>3700 \mathrm{~m}$ water depth), lower bathyal zone (2600-3600 m), lower middle bathyal zone (1600-2300 $\mathrm{m})$, and upper middle bathyal zone $(<1300 \mathrm{~m})$.

\section{Assemblage A}

The two deepest samples ( 3765 and $4125 \mathrm{~m}$ water depths) contain such agglutinated foraminifer species as Rhabdamminella sp., Haplophragmoides sp., and Trochammina sp. The absence of calcareous foraminifers (Table 2) marks the zone deeper than the carbonate compensation depth (CCD).

\section{Assemblage B}

Deep-sea agglutinated species such as Oculosiphon sp., Saccorhiza ramosa (Brady), and Eggerella bradyi Cushman and calcareous species such as Pullenia bulloides (d'Orbigny), Alabamina sp., Astrononion pusillum Hornibrook, Bolivina pusilla Schwager, and Cibicidoides wuellerstorfi (Schwager) characterize five samples recovered from depths between 3567 and $2649 \mathrm{~m}$ in the lower bathyal zone. Among these species, A. pusillum occurs continuously and abundantly from the upper part of this zone to the lower middle bathyal zone. The lack of Bulimina aculeata d'Orbigny as well as the dominance of such primitive agglutinated species as Oculosiphon sp. and $S$. ramosa define the lower bathyal zone.

\section{Assemblage C}

The occurrence of Bulimina aculeata defines the lower middle bathyal zone. Bulimina aculeata is one of the most abundant species together with A. pusillum in this zone. Other dominant species are Bolivina pusilla, Alabamina sp., Pullenia bulloides, Sphaeroidina bulloides d'Orbigny, Oculosiphon sp., Saccorhiza ramosa, Melonis barleeanus (Williamson), Pyrgo murrhina Schwager, and Eggerella bradyi.

The occurrence of Sigmoilopsis schlumbergeri (Silvestri), Uvigerina hispida, and Uvigerina hispidocostata Cushman and Todd is 


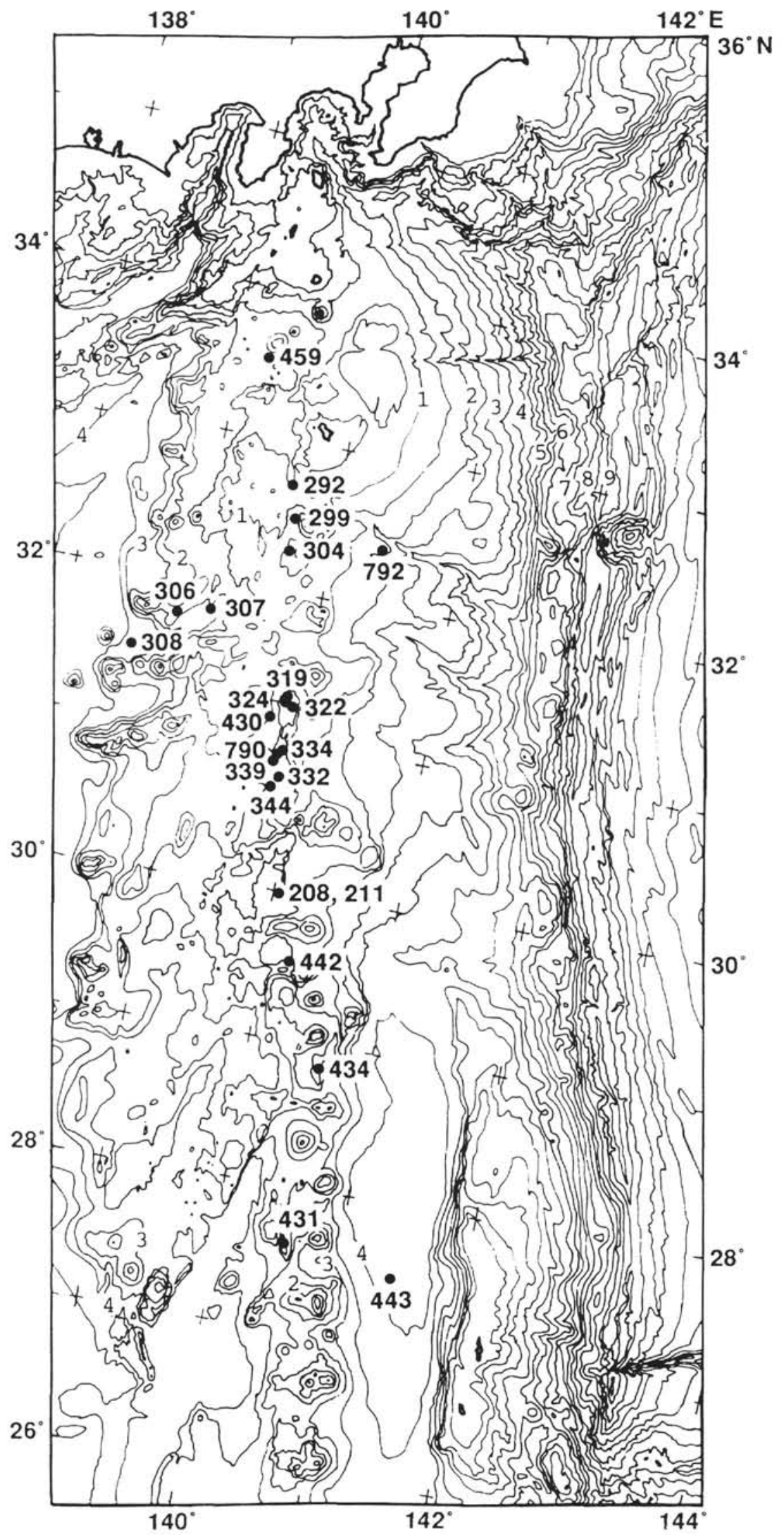

Figure 1. Bathymetric map (500-m contour interval) of the Izu-Bonin region (Taylor et al., this volume) 


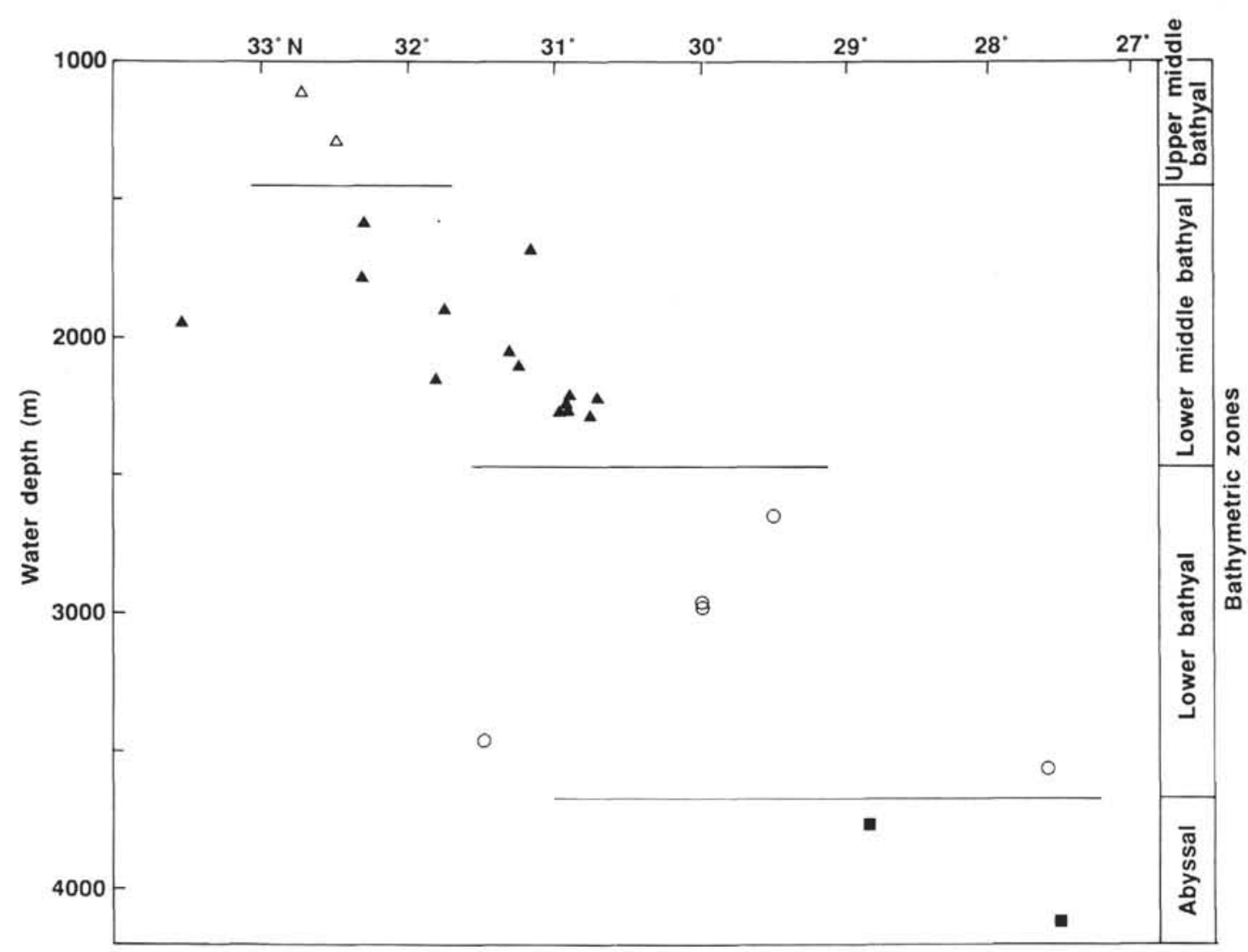

Figure 2. Distribution of Holocene benthic foraminifer assemblages and bathymetric zones in the Izu-Bonin region. Solid squares = Assemblage $\mathrm{A}$, open circles $=$ Assemblage $\mathrm{B}$, solid triangles $=$ Assemblage $\mathrm{C}$, and open triangles $=$ Assemblage $\mathrm{D}$.

Table 1. List of samples used for foraminifer analysis in the Izu-Bonin region.

\begin{tabular}{|c|c|c|c|c|}
\hline $\begin{array}{c}\text { Sample no. } \\
\text { for } \\
\text { Table } 2\end{array}$ & $\begin{array}{l}\text { Sample no. } \\
\text { or core, section, } \\
\text { interval }(\mathrm{cm})\end{array}$ & $\begin{array}{l}\text { Latitude } \\
\text { (N) }\end{array}$ & $\begin{array}{l}\text { Longitude } \\
\text { (E) }\end{array}$ & $\begin{array}{l}\text { Depth } \\
\text { (mbsl) }\end{array}$ \\
\hline 1 & RC292, 4-5 & $32^{\circ} 43.78^{\prime}$ & $139^{\circ} 35.64^{\prime}$ & 1109 \\
\hline i & RC299, 4-5 & $32^{\circ} 30.13^{\prime}$ & $139^{\circ} 35.64^{\prime}$ & 1290 \\
\hline 3 & $\mathrm{RC} 304,4-5$ & $32^{\circ} 16.08^{\prime}$ & $139^{\circ} 39.55^{\prime}$ & 1590 \\
\hline 4 & $\mathrm{RC} 430,4-5$ & $31^{\circ} 25.62^{\prime}$ & $139^{\circ} 44.98^{\prime}$ & 1680 \\
\hline 5 & $126-792 \mathrm{~B}-1 \mathrm{H}-1,2-4$ & $32^{\circ} 23.96^{\prime}$ & $140^{\circ} 22.81^{\prime}$ & 1782 \\
\hline 6 & $\mathrm{RC} 306,4-5$ & $31^{\circ} 45.06^{\prime}$ & $138^{\circ} 50.89^{\prime}$ & 1900 \\
\hline 7 & RC459, 4-5 & $33^{\circ} 31.47^{\prime}$ & $139^{\circ} 14.46^{\prime}$ & 1945 \\
\hline 8 & $\mathrm{RC} 319,4-5$ & $31^{\circ} 19.08^{\prime}$ & $139^{\circ} 50.18^{\prime}$ & 2052 \\
\hline 9 & $\mathrm{RC} 324,4-5$ & $31^{\circ} 17.03^{\prime}$ & $139^{\circ} 50.23^{\prime}$ & 2075 \\
\hline 10 & $\mathrm{RC} 322,4-5$ & $31^{\circ} 14.97^{\prime}$ & $139^{\circ} 53.36^{\prime}$ & 2105 \\
\hline 11 & $\mathrm{RC} 307,4-5$ & $31^{\circ} 48.06^{\prime}$ & $139^{\circ} 07.18^{\prime}$ & 2154 \\
\hline 12 & RC $339,4-5$ & $30^{\circ} 52.33^{\prime}$ & $139^{\circ} 48.20^{\prime}$ & 2212 \\
\hline 13 & $\mathrm{RC} 344,4-5$ & $30^{\circ} 42.27^{\prime}$ & $139^{\circ} 49.96^{\prime}$ & 2220 \\
\hline 14 & $126-790 \mathrm{~A}-1 \mathrm{H}-1,2-4$ & $30^{\circ} 54.95^{\prime}$ & $139^{\circ} 50.66^{\prime}$ & 2222 \\
\hline 15 & $\mathrm{RC} 334,4-5$ & $30^{\circ} 57.94^{\prime}$ & $139^{\circ} 53.13^{\prime}$ & 2279 \\
\hline 16 & RC $332,4-5$ & $30^{\circ} 49.89^{\prime}$ & $139^{\circ} 53.14^{\prime}$ & 2286 \\
\hline 17 & $\mathrm{RC} 442,4-5$ & $29^{\circ} 32.96^{\prime}$ & $139^{\circ} 12.29^{\prime}$ & 2649 \\
\hline 18 & RC211, 4-5 & $29^{\circ} 59.88^{\prime}$ & $140^{\circ} 02.66^{\prime}$ & 2960 \\
\hline 19 & $\mathrm{H} 208,4-5$ & $29^{\circ} 59.97^{\prime}$ & $140^{\circ} 01.56^{\prime}$ & 2980 \\
\hline 20 & RC $308,4-5$ & $31^{\circ} 30.04^{\prime}$ & $138^{\circ} 32.02^{\prime}$ & 3464 \\
\hline 21 & RC431, 4-5 & $27^{\circ} 35.80^{\prime}$ & $140^{\circ} 32.92^{\prime}$ & 3567 \\
\hline 22 & $\mathrm{RC} 434,4-5$ & $28^{\circ} 50.96^{\prime}$ & $140^{\circ} 35.15^{\prime}$ & 3765 \\
\hline 23 & $\mathrm{RC} 443,4-5$ & $27^{\circ} 30.10^{\prime}$ & $141^{\circ} 23.86^{\prime}$ & 4125 \\
\hline
\end{tabular}

restricted to this zone, Sphaeroidina bulloides to the middle bathyal zone, and Karrerulina apicularis (Cushman) to the lower part of the lower middle bathyal and the lower bathyal zones. Oculosiphon sp. is abundant in the lower part of the lower middle and lower bathyal zones. The species composition in the lower part of this zone slightly differs from that in the upper part because of the presence of Karrerulina apicularis (Cushman), abundant Oculosiphon sp., and rare Chilostomella ${ }^{\circ}$ oolina Schwager, and the lack of Neouvigerina ampullacea (Brady). The boundary water depth of the lower and upper parts lies between 2154 and $1945 \mathrm{~m}$. Three samples between 2105 and $2052 \mathrm{~m}$ depths have intermediate characteristics between the lower and upper parts.

\section{Assemblage D}

Both the lack of Bulimina aculeata and the dominance of such species as Neouvigerina ampullacea (Brady), Sphaeroidina bulloides, Cibicidoides wuellerstorfi, Chilostomella oolina, Paracassidulina sagamiensis (Asano and Nakamura), and Pyrgo murrhina characterize the upper middle bathyal zone. These species are most dominant in this zone except for $P$. murrhina, which is also common in the lower part. This fauna suggests the least oxygenated bottom-water condition among the faunas studied.

\section{DISCUSSION}

Most of the Holocene species encountered in this study, including Bulimina aculeata, first appeared in the Pliocene to Oligocene (van Morkhoven, 1986). Thus, the results of this study worked well in estimations of Quaternary and Pliocene paleobathymetry in the IzuBonin region (Kaiho, this volume).

In view of the results of this study, three water depths are important for paleobathymetric interpretation: namely, the CCD and the deepest and shallowest depths of occurrence of $B$. aculeata. We can estimate these three depths as $3700 \mathrm{~m}$ for the CCD, $2300 \mathrm{~m}$ for the deepest occurrence of $B$. aculeata, and $1600 \mathrm{~m}$ for the shallowest occurrence of B. aculeata.

In other areas on the Pacific side of Japan, the shallowest occurrence of B. aculeata is about $1000 \mathrm{~m}$ or shallower, but the deepest occurrence appears to be stable around $2300 \mathrm{~m}$ (Inoue, 1989; Akimoto, 1989; Yasuda, 1989). The CCD in the Shikoku Basin is deeper than $4000 \mathrm{~m}$ (Akimoto, 1989). Of the three depths that are useful for 
Table 2. Distribution chart of Holocene benthic foraminifers.

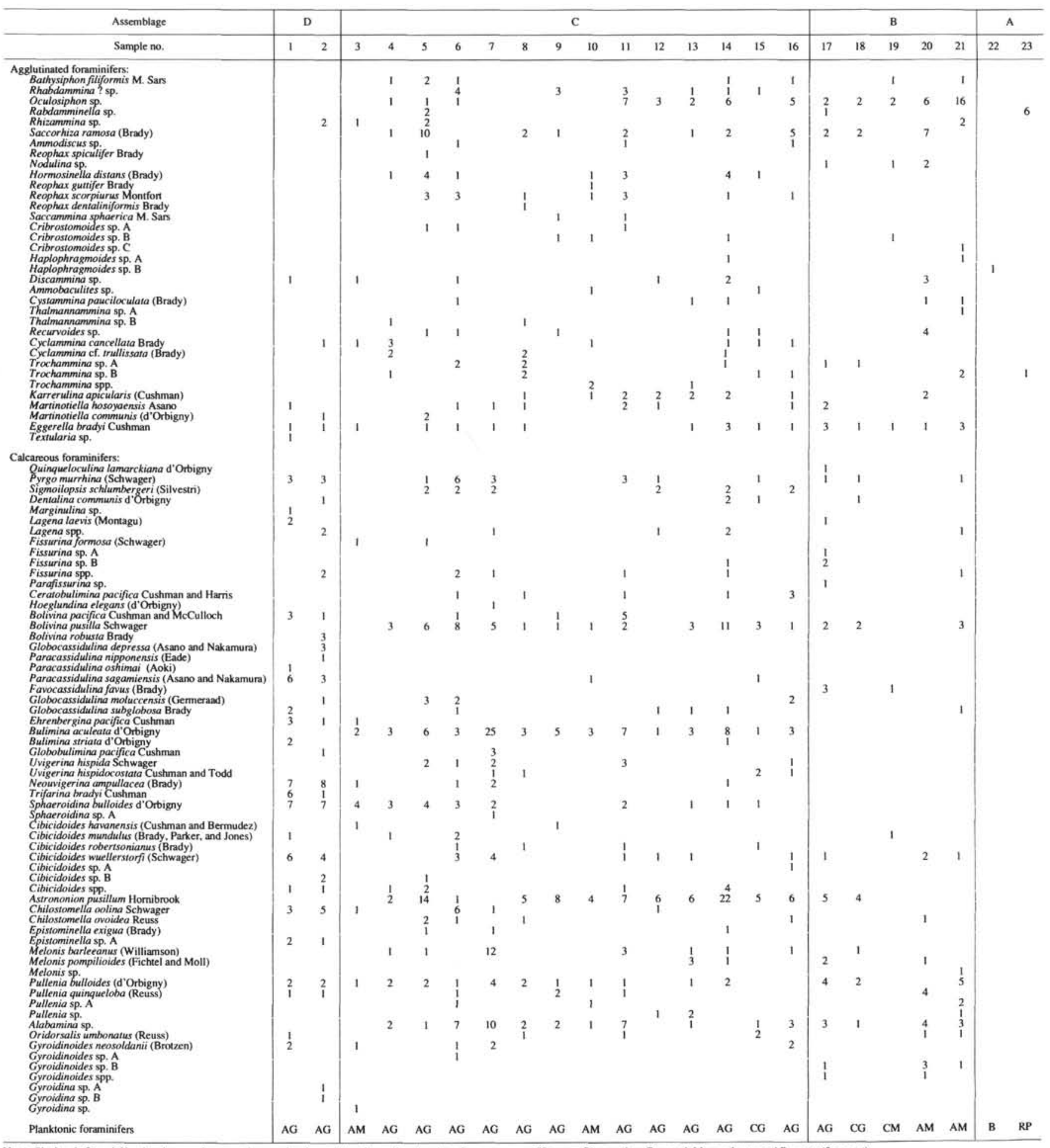

Notes: Planktonic foraminifer abundance and preservation are also shown. Abundance: $\mathrm{A}=$ abundant, $\mathrm{C}=$ common, and $\mathrm{R}=$ rare. Preservation: $\mathrm{G}=$ good, $\mathrm{M}=\mathrm{moderate}$, and $\mathrm{P}=$ poor (fragment).

reconstructing the paleobathymetry of the Izu-Bonin region, only the deepest habitat of $B$. aculeata is effective for estimating the paleodepth in other areas on the Pacific side of Japan.

\section{CONCLUSIONS}

The CCD in the Izu-Bonin region lies between water depths of 3567 and $3765 \mathrm{~m}$. Furthermore, Bulimina aculeata is a good marker for the estimation of paleobathymetry. The shallowest $(1590 \mathrm{~m})$ and deepest $(2286 \mathrm{~m})$ occurrences of this taxon define three bathymetric zones (upper middle bathyal, lower middle bathyal, and lower bathyal) in the Izu-Bonin region. Thus, we can use these three water-depths $-3700 \mathrm{~m}$ for the CCD, $2300 \mathrm{~m}$ for the deepest habitat of Bulimina aculeata, and $1600 \mathrm{~m}$ for the shallowest habitat of $B$. aculeata - to estimate Quaternary and Pliocene paleobathymetry in the Izu-Bonin region. 


\section{ACKNOWLEDGMENTS}

We would like to thank the co-chief scientists, B. Taylor and K. Fujioka, for their encouragement during the course of the present study. We are very grateful to T. Saito and Y. Takayanagi for reviewing the manuscript.

\section{REFERENCES}

Akimoto, K., 1989. Recent foraminifera from Enshunada. In Takayanagi, Y., and Ishizaki, K. (Eds.), Collected Papers on Foraminifera from the Japanese Islands: Sendai (Toko Press), 93-104. (In Japanese)

Inoue, Y., 1989. Northwest Pacific foraminifera as paleoenvironmental indicators. Sci. Rept. Inst. Geosci., Univ. Tsukuba, Sec. B, 10:57-162. van Morkhoven, FP.C.M., Berggren, W. A., Edwards, A. S., et al., 1986. Cenozoic cosmopolitan deep-water benthic foraminifera. Bull. Cent. Rech. Explor-Prod. Elf-Aquitaine, Mem. 11.

Yasuda, H., 1989. Benthic foraminifera and sedimentary facies of the lower slope basin off Shikoku, Japan. In Takayanagi, Y., and Ishizaki, K. (Eds), Collected Papers on Foraminifera from the Japanese Islands: Sendai (Toko Press), 83-92. (In Japanese)

Date of initial receipt: 31 October 1990

Date of acceptance: 18 March 1991

Ms 126B-138 


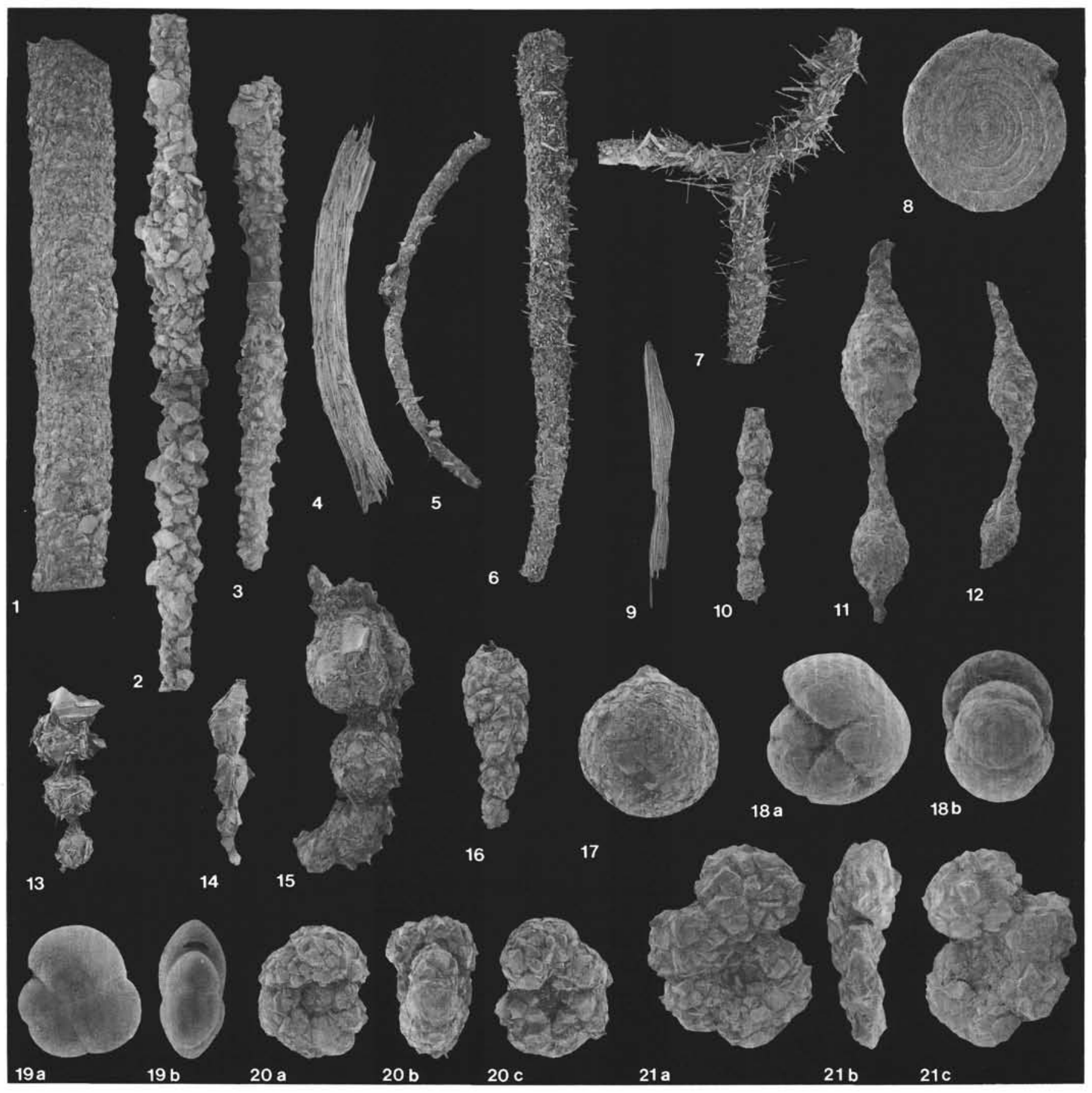

Plate 1. 1. Rhabdammina? sp., Sample RC307, $4-5 \mathrm{~cm}(21 \times)$. 2,3. Oculosiphon sp.; (2) Sample RC431, 4-5 cm (21×); (3) Sample RC307, 4-5 cm (21×). 4. Rabdamminella sp., Sample 126-792B-1H-1, 2-4 cm (21×). 5. Rhizammina sp., Sample RC299, 4-5 cm (21×). 6, 7. Saccorhiza ramosa (Brady); (6) Sample RC319, 4-5 cm (21×); (7) Sample 126-792B-1H-1, 2-4 cm (21×). 8. Ammodiscus sp., Sample RC332, 4-5 cm (33×). 9. Reophax spiculifer Brady, Sample 126-792B-1H-1, 2-4 cm (21×). 10. Nodulina sp., Sample RC308, 4-5 cm (21×). 11, 12. Hormosinella distans (Brady), Sample 126-790A-1H-1, 2-4 cm (21×). 13. Reophax guttifer Brady, Sample RC $322,4-5 \mathrm{~cm}(47 \times)$. 14, 15. Reophax scorpiurus Montfort; (14) Sample RC332, 4-5 cm (21×) ; (15) Sample RC307, 4-5 $\mathrm{cm}(21 \times)$. 16. Reophax dentaliniformis Brady, Sample RC319, 4-5 cm (21x). 17. Saccammina sphaerica M. Sars, Sample RC324, 4-5 cm (33x). 18. Cribrostomoides sp. A, Sample RC306, 4-5 cm (33× ). 19. Cribrostomoides sp. B, Sample 126-790A-1H-1, 2-4 cm (47×). 20. Haplophargmoides sp. A, Sample RC431, 4-5 cm (21×). 21. Discammina sp., Sample RC304, 4-5 cm (21×). 


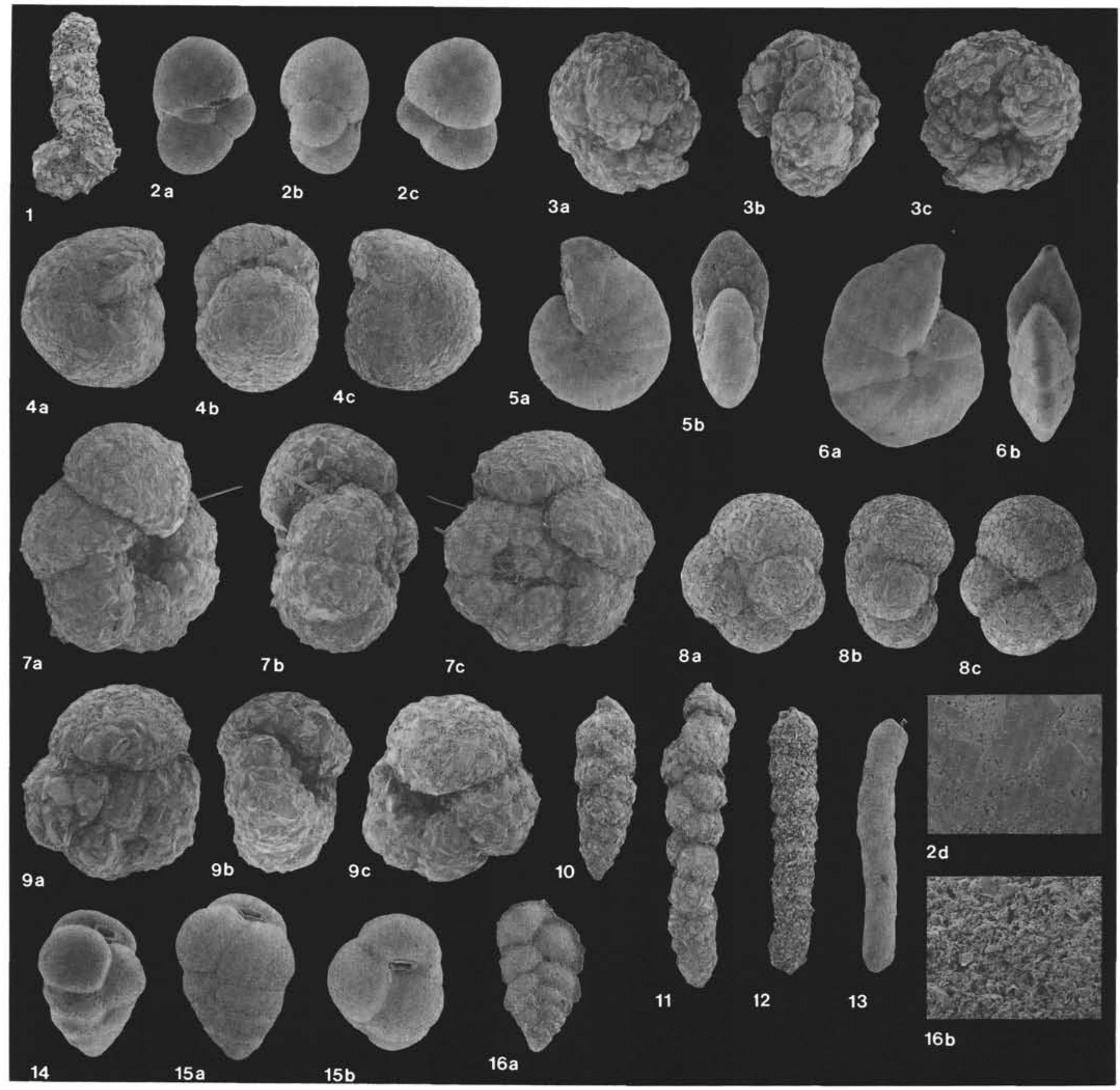

Plate 2. 1. Ammobaculites sp., Sample RC $322,4-5 \mathrm{~cm}(21 \times)$. 2. Cystammina pauciloculata (Brady), Sample RC $344,4-5 \mathrm{~cm}$ ( $2 \mathrm{a}-\mathrm{c}, 46 \times 2 \mathrm{~d}, 698 \times$ ). 3. Thalmannammina sp. A, Sample RC431, 4-5 cm (21×). 4. Recurvoides sp, Sample RC308, 4-5 cm (33×). 5. Cyclammina cancellata Brady, Sample RC334, 4-5 cm (21×) 6. Cyclammina cf. trullissata (Brady), Sample RC $319,4-5 \mathrm{~cm}(33 \times)$. 7,9. Trochammina sp. A, Sample RC $319,4-5 \mathrm{~cm}(7,21 \times 9,33 \times)$. 8. Trochammina sp. B, Sample RC319, 4-5 cm (33x). 10, 11. Karrerulina apicularis (Cushman); (10) Sample RC308, 4-5 cm (37x); (11) Sample RC319, 4-5 cm (33×). 12. Martinotiella hosoyaensis Asano, Sample RC306, 4-5 cm (21×). 13. Martinotiella communis (d’Orbigny), Sample RC299, $4-5 \mathrm{~cm}(21 \times)$. 14, 15. Eggerella bradyi Cushman; (14) Sample RC442, 4-5 cm (33x) ; (15) Sample RC319, 4-5 cm (33x). 16. Textularia sp., Sample RC292, 4-5 cm (16a, 21×; 16b, 698×). 


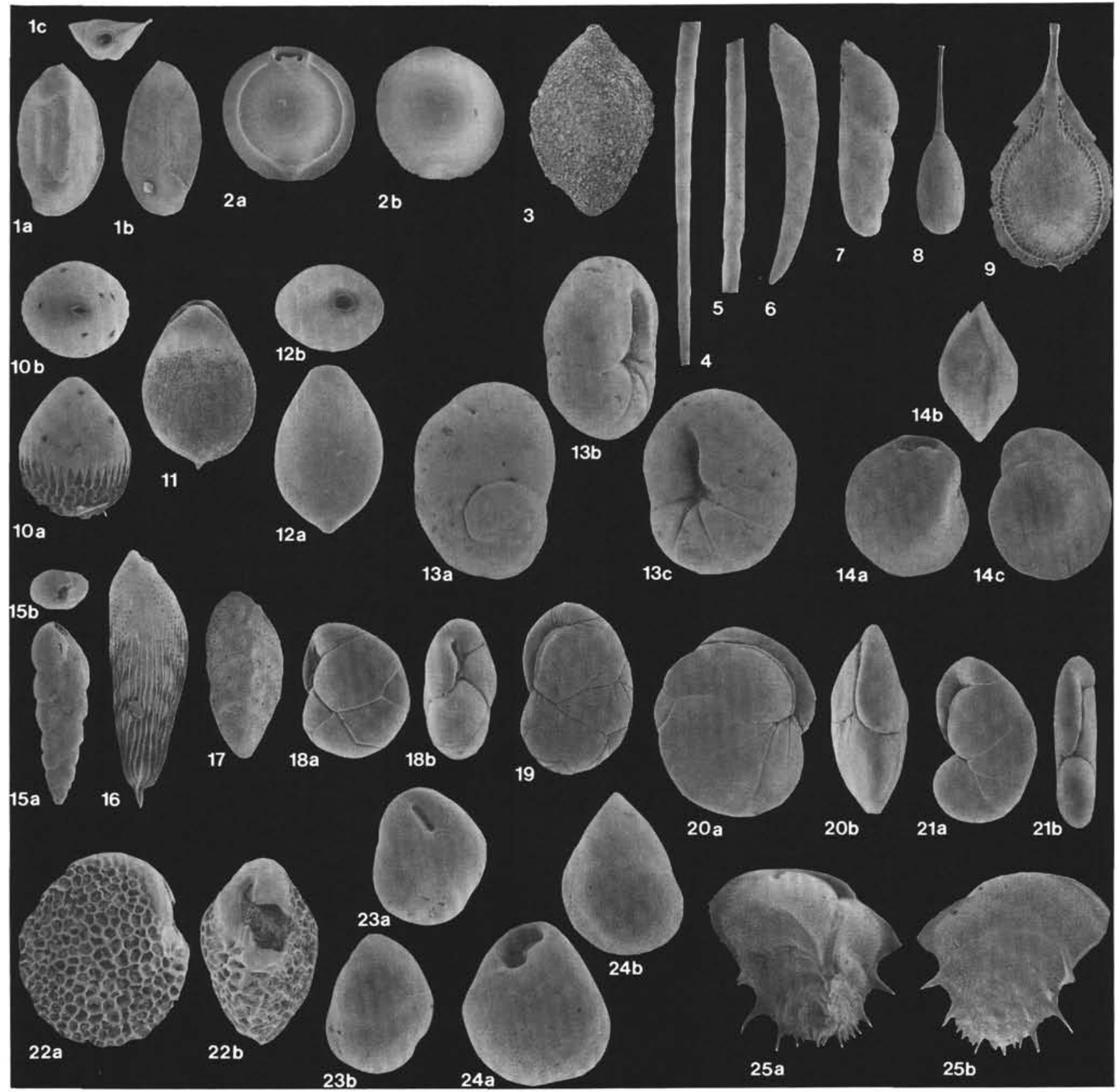

Plate 3. 1. Quinqueloculina lamarckiana d'Orbigny, Sample RC442, 4-5 cm (33x). 2. Pyrgo murrhina (Schwager), Sample RC459, 4-5 cm (21x). 3. Sigmoilopsis schlumbergeri (Silvestri), Sample RC332,4-5 cm (33x). 4, 5. Bathysiphon filiformis M. Sars; (4) Sample RC430, 4-5 cm (21×); (5) Sample RC431, 4-5 cm (21×). 6. Dentalina communis d'Orbigny, Sample 126-790A-1H-1, 2-4 cm (21×). 7. Marginulina sp., Sample RC292, 4-5 cm (21×). 8. Lagena laevis (Montagu), Sample RC442, 4-5 cm (48×). 9. Fissurina formosa (Schwager), Sample RC 304, 4-5 cm (48×). 10. Fissurina sp. A, Sample RC442, 4-5 cm (33x). 11. Parafissurina sp., Sample RC442, 4-5 cm (48x). 12. Fissurina sp. B, Sample 126-790A-1H-1, 2-4 cm (72x). 13. Ceratobulimina pacifica Cushman and Harris, Sample RC319, 4-5 cm (33x). 14. Hoeglundina elegans (d'Orbigny), Sample RC459, 4-5 cm (48x). 15. Bolivina pacifica Cushman and McCulloch, Sample RC292, 4-5 cm (21×). 16. Bolivina pusilla Schwager, Sample 126-792B-1H-1, 2-4 cm (72×). 17. Bolivina robusta Brady, Sample RC299, $4-5 \mathrm{~cm}(48 \times)$ ). 18. Globocassidulina depressa (Asano and Nakamura), Sample RC299, 4-5 cm (72x). 19 . Paracassidulina nipponensis (Eade), Sample RC299, 4-5 cm (72×). 20. Paracassidulina sagamiensis (Asano and Nakamura), Sample RC299, 4-5 cm (72x). 21. Paracassidulina oshimai (Aoki), Sample RC292, $4-5 \mathrm{~cm}(72 \times)$ ). 22. Favocassidulina favus (Brady), Sample RC442, 4-5 cm (33×). 23. Globocassidulina subglobosa Brady, Sample RC431, 4-5 cm (21×). 24. Globocassidulina moluccensis (Germeraad), Sample 126-792B-1H-1, 2-4 cm (72x). 25. Ehrenbergina pacifica Cushman, Sample RC299, 4-5 cm (72X). 


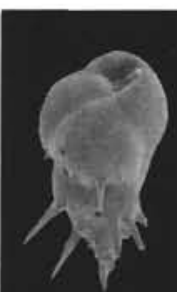

1

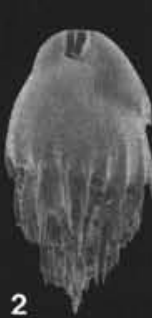

3

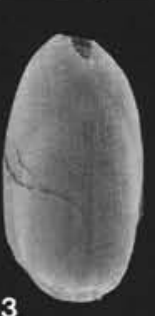

4

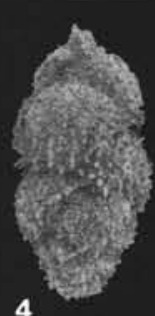

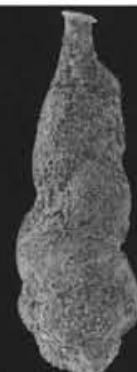

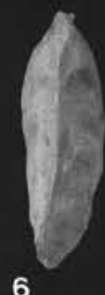

6

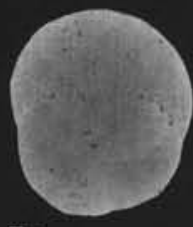

$7 a$

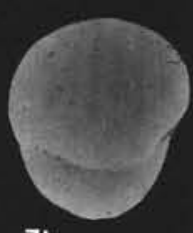

$7 b$

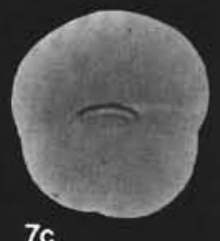

$7 \mathrm{c}$

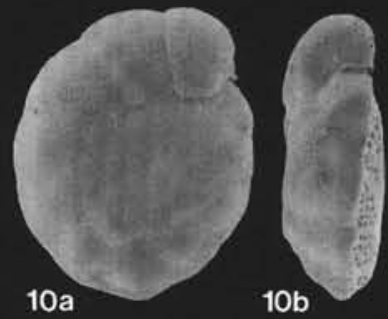

$9 b$

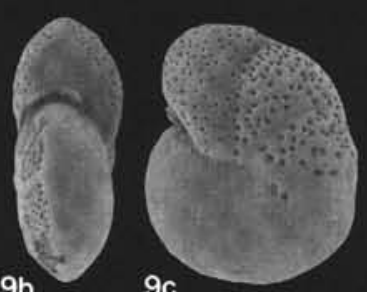

108

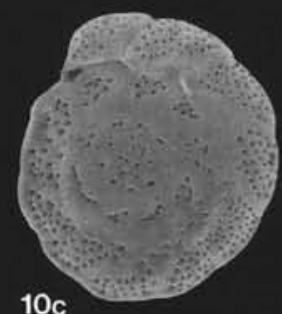

$12 \mathrm{c}$

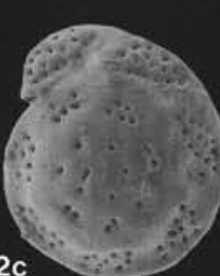

$10 c$
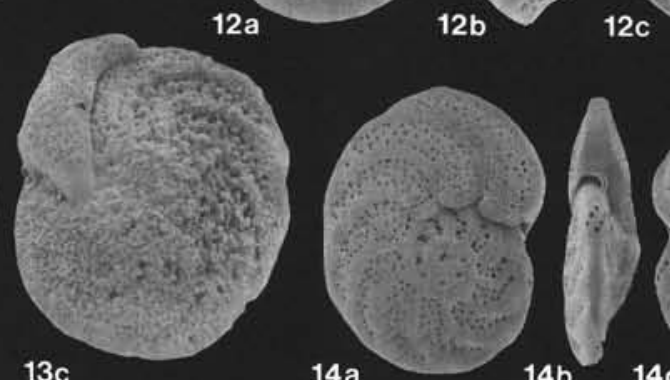

$14 c$

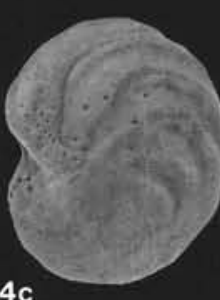

$15 a$

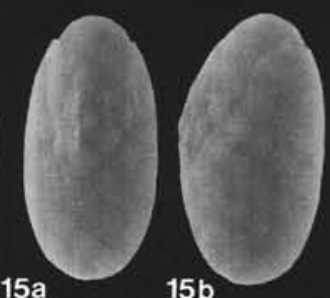

$15 b$

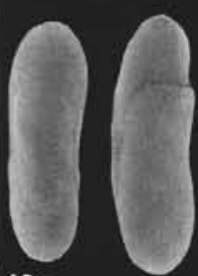

$16 a$

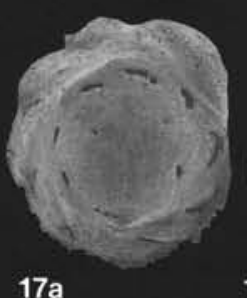

$17 \mathrm{a}$
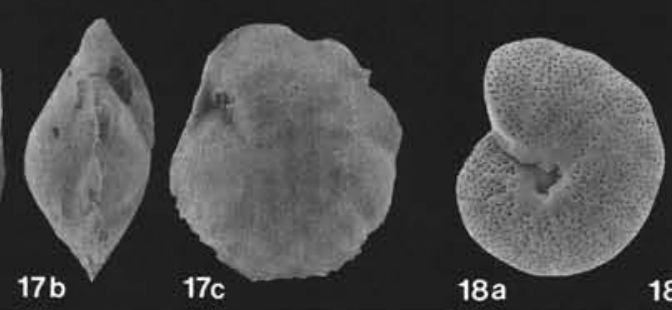

$18 \mathrm{a}$

$18 b$
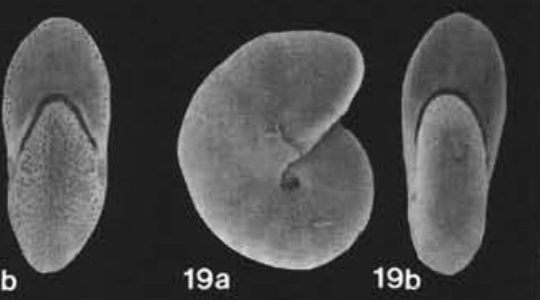

Plate 4. 1. Bulimina aculeata d'Orbigny, Sample RC459, $4-5 \mathrm{~cm}(33 \times)$. 2. Bulimina striata d'Orbigny, Sample RC292, $4-5 \mathrm{~cm}(48 \times)$. 3 Globobulimina pacifica Cushman, Sample RC459, 4-5 cm (33×). 4. Uvigerina hispidocostata Cushman and Todd, Sample RC $319,4-5 \mathrm{~cm}$ ( $33 \times$ ). 5. Uvigerina proboscidea Schwager, Sample RC292, 4-5 cm (72×). 6. Trifarina bradyi Cushman, Sample RC299, 4-5 cm (48x). 7. Sphaeroidina bulloides d'Orbigny, Sample 126-7.92B-1H-1, 2-4 cm (33×). 8. Sphaeroidina sp. A, Sample RC459, 4-5 cm (33×). 9. Cibicidoides sp. A, Sample RC $332,4-5 \mathrm{~cm}(33 \times)$. 10. Cibicidoides robertsonianus (Brady), Sample RC306, 4-5 cm (33x). 11. Cibicidoides mundulus (Brady, Parker, and Jones), Sample RC430, 4-5 cm (33x). 12. Cibicidoides havanensis (Cushman and Bermudez), Sample RC344, 4-5 cm (48x). 13. Cibicidoides $\mathrm{sp}$. B, Sample RC299, $4-5 \mathrm{~cm}$ (33x). 14. Cibicidoides wuellerstorfi (Schwager), Sample RC459, 4-5 cm (33×). 15. Chilostomella oolina Schwager, Sample RC459, 4-5 cm (33×). 16. Chilostomella ovoidea Reuss, Sample $\mathrm{RC} 319,4-5 \mathrm{~cm}(33 \times)$. 17. Osangularia bengalensis (Schwager), Sample 126-790A-1H-1, $2-4 \mathrm{~cm}(72 \times)$. 18. Melonis barleeanus (Williamson), Sample RC459, 4-5 cm (48x). 19. Melonis sp., Sample RC431, 4-5 cm (48x). 


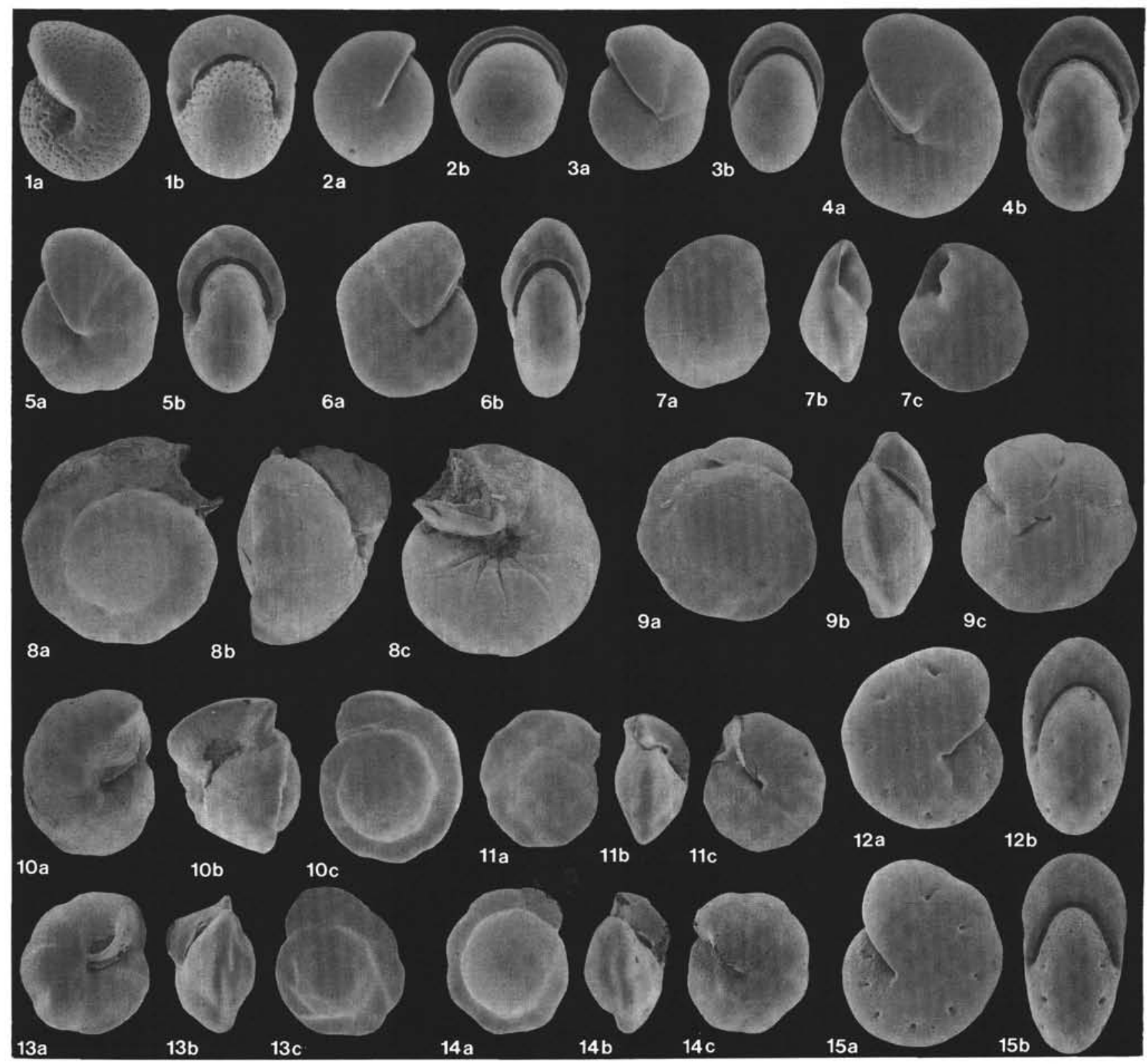

Plate 5. 1. Melonis pompilioides (Fichtel and Moll), Sample RC308, 4-5 cm (48x). 2. Pullenia bulloides (d'Orbigny), Sample 126-792B-1H-1, 2-4 cm (48x). 3, 4. Pullenia sp. A; (3) Sample RC431, 4-5 cm (48x); (4) Sample RC322, 4-5 cm (48x). 5, 6. Pullenia quinqueloba (Reuss); (5) Sample RC324, 4-5 cm (72 $\times$ ) ; (6) Sample RC324, 4-5 cm (72×). 7. Alabamina sp., Sample RC306, 4-5 cm (72×). 8. Gyroidinoides neosoldanii (Brotzen), Sample $\mathrm{RC} 304,4-5 \mathrm{~cm}(21 \times)$. 9. Oridorsalis umbonatus (Reuss), Sample RC334, 4-5 cm (33×). 10. Gyroidinoides sp. A, Sample RC306, $4-5 \mathrm{~cm}(48 \times) . \quad 11$. Gyroidina sp. A, Sample RC299, 4-5 cm (48x). 12, 15. Astrononion pusillum Hornibrook, Sample 126-792B-1H-1, 2-4 cm (72×). 13. Gyroidinoides sp. B, Sample RC431, 4-5 cm (48x). 14. Gyroidina sp. B, Sample RC299, 4-5 cm (48x). 